\title{
Women Empowerment through Education in Nurpur Shahan
}

\author{
Ammarah Aftab
}

\begin{abstract}
The concern for women empowerment has been a priority in the docket of many national and international stakeholders in Pakistan. Yet, the challenges faced by the country's women have failed to be substantially mitigated. Though, the reasons for this are many, there is a unanimous agreement on the one pertaining to illiteracy. The study looks to elicit feedback and insight from the perspective of rural women about the degree to which the procuration of education can alleviate their position in the society. For the purpose, a total of 75 women fromNurpur Shahan (a bucolic locality of Islamabad) were randomly sampled and interviewed.Their standpoint on how to make the acquisition of education more feasible for them was also taken into consideration. The conclusion wasas follows: literacy was indeed recognized by these women as a valuable tool for their economic empowerment and that they held every desire to participate in education programs provided they get both, moral and financial support from their homes.
\end{abstract}

Keywords: Illiteracy; Women Empowerment; Pakistan; Education.

\section{Introduction}

'Empowerment' is a debated intellection, concealing different definitions stemming from the disparateness in the perspectives of viewing the term. The definitions, due to their intricacy, are often the topic of debate amongst sociologists. Yet, ingrained in the word is power, an asset found in unequal distribution in the world-indicating that empowerment is the panacea for inequality(UNICEF, 2007). Women empowerment, thus defined, is the need to transform the nature of power relations (Zoë Oxaal, 1997).

The relationship between education and women empowerment rests on the belief that economic stability is a consequential precursor to women empowerment and thatwomen empowerment and economic development are closely related(Duflo, 2012). Therefore,education, economic stability and women empowerment happen in consequence to one another. In other words, the educated has more earning power than the uneducated and that earning power is a manifestation of one's intellectual standing which if higher, translates into a greater level of self-esteem, independence and hence empowerment.

Yet, with an overall literacy rate as low as 58 percent (Government of Pakistan ministry of finance, 2015), Pakistan has foundered to take its education sector to the standard mandatory for the social uplifting of a society. The situation is calamitous for women in particular with the percentage of out-of-school female students being the third largest in the world(UNESCO, 2012). The plight is the most devastating in NWFP and Baluchistan where female literacy rate falls between 3 to 8 percent. Worst still,while boys enrolling in primary schools are given a fair chance of completing their education, as much as 48 percent of the girls are impoverished of the same(Alif Ailaan, 2012) .Finally, the educational facilities in Pakistan for females is also poor-out of 63,914 public schools for girls, $15.3 \%$ are without a building, $61 \%$ lack electricity, 42.4\% lack outhouses, $44.3 \%$ lack boundary walls, $3.8 \%$ are declared dangerous while another $16.1 \%$ are in need of major repairs(Academy of educational planning and management, 2013).
What the statistics above accentuates is the considerable gender gap in the education of Pakistan and the lack of investment in education. It is relevant to point out that the figures are so even when the rate of returns in women's education is higher than that of men(P.Todaro, 2007). Still,while education for men is more accessible and always emboldened, women remain forsaken from academic pursuits merely due to the prevalent religious and patriarchal ideology that continues to limit, enslave and infract the females of the country(A.Sathar \& Raza, 1994). The bigoted treatment, while fortifying the predominant income differential between the sexes, makes women dependent on men in a way often employed in the bereavement of their rights.

The solution is not merely to applaud women education but also to commend its utilization. For, the regressive societal roles pervasive in the milieu of Pakistan confine women to domestic duties even after the acquisition of alternative skills. Every year, for instance, only 50 percent of females who graduate from medical colleges actually practice medicine (Pakistan medical and dental council , 2014). And the reason by large is the society concussing females tolay focus solely on domestic responsibilities. The foregoingethos grants economic powers exclusively to a man and also the self-esteem annexed with it.

What hence, the women require is comprehensive empowerment through support for not only their education but also their economic participation. The aforementioned will embellish their skillset, equip them with venues to showcase their talents, induce their dignity to develop andextricate them from subservience to men.

Most importantly, the percentage of female population in Pakistan is around 50 percent (Trading economics, 2013), making it only necessary to bolster femaleattendance in the economy. The concomitant increase inthe labor force will provide for the economic development of the country (Parveen, 2008) and produce institutions representative of a diverse set of voices. This is not to say that women in Pakistan, at present, are not working. Rather, it is to convey that they are deprived of the education necessary to participate in the labor market in a more formal sense, 


\section{International Journal of Science and Research (IJSR) \\ ISSN (Online): 2319-7064 \\ Index Copernicus Value (2013): 6.14 | Impact Factor (2014): 5.611}

leaving them to perform only menial and strenuous tasks with inappreciable wages and in turn contribute towards the hefty percentage of the Pakistani population living below the poverty line(P.Todaro, 2007).

Related to the role of education in easing economic burden comes its function in dropping the birth-rate of a country. It is reported that women with no education have about twice the number of children as women with tenor more years of school (Measure communication, 2000). Above all, there is empirical evidence that education equips women with better child bearing decisions(Measure communication, 2000), hence establishing its multitudinal effects on every member of each women's household.

Yet, nothing consequential has emerged with respect to bettering the female literacy rate of Pakistan. This by no means should be perceived as a prognostic of lack of potential in the women of the country. Rather, it is purely a reminder of the male chauvinism rampant particularly in the pastoral localities of the country where most women have no option but to resign to the will of those male existences who consider it their birthright to humiliate and degrade them. Religion in these domains is an institution misapplied to downgrade the presence of women to one that is purposeless. In fact, it would be safe to assume that denying education to women is actually (in most cases at least) done deliberately so as to facilitate the process of their servitude. For, it is only those with unlettered mindsets who do not have the psychological strength needed to demand their rights and raise their voices against atrocities likedomestic violence, rape, sexual harassment, and early marriages, all of which are unbridled in the rustic sectors of Pakistan.

Identifying the paramountcy of education in the promotion of economic growth and human development index, the government has taken a number of measures for its betterment.The Education Policy (2009)for instance, set a mark of $90 \%$ enrollment of children between ages of 5 to 9 (Riaz \& Bhatti, 2010). However, the target is yet to be met. The reasons are: inadequate funds from donor agencies, lack of integrated efforts and gender discrimination (Ashraf, Afzal, \& Shurgeel, 2012).Secondly, poor implementation also precludes many literary programs from reaching a favorable outcome. Some examples of such failed mega projects are the Social Action Programme (SAP I \& II), the Sindh Primary Education Development Project (SPEDP), the Girls Primary Education Development Project I \& II (GPEDP) and the Primary Education Curriculum Reform Project (PECRP) (S.Mustafa, 2014).

The problem in implementation of education policy in Pakistan establishes the notion that policy extends beyond its formulation. Also, most plans are feeble in learning from their past and hence fail to meet the chimerical objectives forming their bases(Ali, 2006).One of the main reason behind the occurrence of such a situation is the unavailability of accurate data pertinent to the education sector in Pakistan(Ahsan, 2003). Furthermore, teaching is not regarded as a sought after profession in the countryand hence is primarily occupied by those who have failed to get jobs in public sectors. Thisleads to a paucity of individuals willing to teach or a scarcity of motivation in those who do, hence curtailing the resources needed for the success of any education scheme in pastoral districts.

In Islamabad, slums are found at the center of the urban sectors, particularly on the banks of the riverine nullas. Many ofthese localities are regularized by the capital development authority (CDA) and hence have inhabitants with legal housing.Yet, despite the denizens being legitimate members of the community, mostare deprived of basic schooling facilities. Consequently, the literacy rate of the slums of Islamabadis as low as 14.92 percent(The Nation, 2012).

Nurpur Shahan being an old village located around $7 \mathrm{~km}$ from Islamabad, is a meed of the aforesaid typology. The area has settlements from all provinces of Pakistan, representsa marginalized segment of the world, and is an archetype of a legion of issues pertaining to female education. Hence, it was chosen as a surveillance site for the present study.

The paper, therefore, looks to provide an insight in the female literacy needs of the Arcadian territories and intends to aid the drawing of an effective educational scheme for women along with asserting itsimportance in their empowerment.

\section{Method}

75 non-literate women located in Nurpur Shahan were randomly selected and used for the study. For the purpose, a questionnaire was drafted.The questionnaire was then translated in Urdu and back translated in English to ensure validity. It was made certain that all the questions were read out to the participants due to their own reading inability and that the questions were proposed in the local language. Furthermore, systematic sampling technique, a category of random sampling was used: in each street the $2^{\text {nd }}, 4^{\text {th }}, 6^{\text {th }}$ and henceforth house was chosen. Five groups of two students were chosen to carry out the surveys. Careful consideration was given to keep both the members in each group female in light of the cultural norms of Nurpur Shahan. Almost all the surveys were carried out in the homes of the concerned female dwellers. Since the answers for each question was conveyed verbally, all communication was audio recorded to supplement the notes made by the researchers. The data collected was then analyzed using frequency counts, percentages and rankings.

\section{Results}

\section{Section 1:}

The first section of the questionnaire dealt with determining the demographic profile of the sample. 


\section{International Journal of Science and Research (IJSR) \\ ISSN (Online): 2319-7064 \\ Index Copernicus Value (2013): 6.14 | Impact Factor (2014): 5.611}

Table 1: Demographic analysis of therespondents

\begin{tabular}{|c|c|c|c|c|}
\hline Section & $\begin{array}{c}\text { Possible } \\
\text { responses }\end{array}$ & $\begin{array}{c}\text { Frequency } \\
\text { (out of 75) }\end{array}$ & Percentage & Rank \\
\hline \multirow{4}{*}{ Age } & $13-19$ & 22 & 29.3 & 1 \\
\cline { 2 - 5 } & $20-29$ & 12 & 16.0 & 4 \\
\cline { 2 - 5 } & $30-39$ & 13 & 17.3 & 3 \\
\cline { 2 - 5 } & $40-49$ & 3 & 4.0 & 6 \\
\cline { 2 - 5 } & 50 and above & 6 & 8.0 & 5 \\
\cline { 2 - 5 } & Do not know & 19 & 25.3 & 2 \\
\hline Primary & Urdu & 15 & 20.0 & 2 \\
\cline { 2 - 5 } & Punjabi & 43 & 57.3 & 1 \\
\cline { 2 - 5 } & Pashto & 6 & 8.0 & 4 \\
\cline { 2 - 5 } & Other & 11 & 14.6 & 3 \\
\hline Marital & Divorced & 0 & 0.0 & 4 \\
\cline { 2 - 5 } & Married & 63 & 84.0 & 1 \\
\cline { 2 - 5 } & Single & 9 & 12.0 & 2 \\
\cline { 2 - 5 } & Widowed & 3 & 4.0 & 3 \\
\hline \multirow{4}{*}{$\begin{array}{c}\text { No of } \\
\text { children }\end{array}$} & 0 & 10 & 13.3 & 3 \\
\cline { 2 - 5 } & 1 & 2 & 2.6 & 6 \\
\cline { 2 - 5 } & 2 & 7 & 9.3 & 4 \\
\cline { 2 - 5 } & 3 & 4 & 5.3 & 5 \\
\cline { 2 - 5 } & 4 & 16 & 21.3 & 2 \\
\cline { 2 - 5 } & More than 4 & 36 & 48.0 & 1 \\
\hline
\end{tabular}

As per table1 most of the participants fell in the age bracket of 20-29 years $(29.3 \%)$ Many $(25.3 \%)$ did not know their age, alluding towards the lack of records of rural birth rates in Pakistan. Moreover, 57.3\% primarilyconversed in Punjabi while $20 \%$ employed the Urdu language more frequently.As many as $84.0 \%$ were married with $48.0 \%$ having more than four children.

\section{Section 2:}

The second section of the questionnaire dealt with determining the extent of empowerment of non-literate women in Nurpur Shahan using four dimensions; Selfesteem, decision making,mobility and economic stability.

Table 2: The extent of women empowerment in Nurpur Shahan.

\begin{tabular}{|c|c|c|}
\hline Dimension & $\begin{array}{l}\text { Frequency } \\
\text { (out of 75) }\end{array}$ & $\begin{array}{c}\text { Percentage } \\
\text { Rank }\end{array}$ \\
\hline \multicolumn{3}{|l|}{ Self-esteem } \\
\hline I feel: Satisfied with myself. & 23 & 30.6 \\
\hline I have a number of good qualities. & 27 & 36.0 \\
\hline I am able to do things as well men. & 5 & 6.6 \\
\hline $\begin{array}{l}\text { My husband is not justified to beat me even when I: } \\
\text { Neglect my children. } \\
\text { Talk to other men. } \\
\text { Disagree with him. } \\
\text { Do not take his permission before doing something. }\end{array}$ & $\begin{array}{l}42 \\
8 \\
9 \\
15 \\
\mathbf{1 2 9 / 5 2 5}\end{array}$ & $\begin{array}{l}56.0 \\
8.6 \\
12.0 \\
20.0 \\
\mathbf{2 4 . 5 1}\end{array}$ \\
\hline \multicolumn{3}{|l|}{ Decision Making } \\
\hline $\begin{array}{l}\text { I decide: } \\
\text { Who I get married to. } \\
\text { Where I work outside home. } \\
\text { Using family planning. } \\
\text { My education. } \\
\text { My children's education. } \\
\text { Purchasing requirements of my children. }\end{array}$ & $\begin{array}{l}7 \\
12 \\
1 \\
2 \\
5 \\
2 \\
\mathbf{2 9 / 4 5 0}\end{array}$ & $\begin{array}{l}9.30 .06 \\
16.0 \\
1.3 \\
2.6 \\
6.6 \\
2.6 \\
\mathbf{6 . 4 3}\end{array}$ \\
\hline \multicolumn{3}{|l|}{ Mobility } \\
\hline $\begin{array}{l}\text { In the last year I: } \\
\text { Visitedmy friends outside the city. } \\
\text { Visited hospital or clinic. }\end{array}$ & $\begin{array}{l}5 \\
16 \\
\mathbf{2 1} / \mathbf{1 5 0} \\
\end{array}$ & \begin{tabular}{|l|}
6.6 \\
21.3 \\
$\mathbf{1 4 2}$ \\
\end{tabular} \\
\hline $\begin{array}{l}\text { Economic stability } \\
\text { I am economically independent. } \\
\text { I can support my children financially. } \\
\text { I have money that I can spend as I wish. }\end{array}$ & $\begin{array}{l}3 \\
3 \\
0 \\
6 / 225\end{array}$ & $\begin{array}{c}4.0 \\
4.0 \\
0.0 \\
2.64\end{array}$ \\
\hline
\end{tabular}

As per table 2, the respondents were seen to have high selfesteem $(24.5 \%)$ relative to the other chosen three indicators of women empowerment. Within the very same indicator however, majority of the women found it acceptable to be beaten by their husbands if they disagreed with him, did something without his permission or talked to other men.

At $14 \%$ the indicator that came second in rank was mobility. Decision making draggled close behind at $6.4 \%$ while economic stability was the indicator least exhibited by the participants $(2.6 \%)$.

\section{Section 3:}

The third section of the questionnaire dealt with determining the extent to which education can improve the indices of each of these indicators in the eyes of the non-literate women in Nurpur Shahan. 


\section{International Journal of Science and Research (IJSR) \\ ISSN (Online): 2319-7064}

Index Copernicus Value (2013): 6.14 | Impact Factor (2014): 5.611

Table 3: The impact of education on women empowerment

\begin{tabular}{|c|c|c|c|}
\hline Dimension & $\begin{array}{c}\text { Frequency } \\
\text { (out of 75) }\end{array}$ & Percentage & Rank \\
\hline Self-esteem & 52 & 69.3 & 3 \\
\hline Decision Making & 41 & 54.6 & 2 \\
\hline Mobility & 15 & 20 & 4 \\
\hline Economic Stability & 73 & 97.3 & 1 \\
\hline
\end{tabular}

As per table 3, 73 respondents regarded education acquisition as cardinal for the improvement of their economic stability.Upon inquiring why, many of them stated better job opportunities as the main reason. $69.3 \%$ of the participants considered education to possibly play a positive role on upgrading their self-esteem. In the aforementioned regard,one respondent said that she felt particularly at a disadvantage to her husband when she had to ask him to read out any letter or bill for her. The weight of education on decision-making power was ranked $3^{\text {rd }}$ in the eyes of the respondents though many of them agreed that with increased awareness and knowledge, they would be in a better position of making sound household decisions. Finally, the impact of education on mobility was ranked lowest at a percentage of a mere $20 \%$ as most of the participants held domestic restrictions being more responsible for their shortfall in motility.

\section{Section 4:}

The fourth section of the questionnaire dealt with determining the main obstacles the respondents faced in acquiring education.

Table 4: The main obstacles in education acquisition

\begin{tabular}{|l|c|c|c|}
\hline \multicolumn{1}{|c|}{ Obstacles } & $\begin{array}{c}\text { Frequency } \\
\text { (out of 75) }\end{array}$ & Percentage & Rank \\
\hline $\begin{array}{l}\text { Lack of time due to household } \\
\text { chores }\end{array}$ & 21 & $28.0 \%$ & 4 \\
\hline Lack of money & 61 & $81.3 \%$ & 2 \\
Lack of support from home. & 65 & $86.6 \%$ & 1 \\
Lack of proper infrastructure & 34 & $45.3 \%$ & 3 \\
Lack of trained teachers & 12 & $16.0 \%$ & 5 \\
Lack of need & 7 & $9.3 \%$ & 6 \\
Lack of motivation & 7 & $9.3 \%$ & 6 \\
\hline
\end{tabular}

As per table 4, as many as $86.6 \%$ of the respondents stated that they do not get any support from their homes with regard to education. Lack of money $(81.3 \%)$ was ranked the second biggest hurdle.Lack of proper infrastructure was the hurdle ranked third at $45.3 \%$ while lack of time was ranked fourth $(28.0 \%) .12 .0 \%$ of the participants perceived lack of trained teachers as an impediment while lack of need and motivation was experienced by a puny percentage of $9.3 \%$.

\section{Discussion}

The study brought some startling personality traits of Nurpur Shahan to the surface, specifically the one pertaining to early marriages and the subsequent expectation of female adolescents to bear children; Though, $29.3 \%$ of the respondents were between 13-19 years of age, as many as $84 \%$ were married and $86.7 \%$ had children. It was mentioned by most respondents that the main reason for marrying them early was because they were perceived as financial burdens by their families. Perhaps that and the prevalent poverty rate in Nurpur Shahan was why the impact of education on economic stability was the parameter taken into most consideration by the respondents $(97.3 \%)$ while either ignoring or potentially being unaware of the many others.

Also, $25.3 \%$ of respondents were oblivious to their age, thus, verifying a lack of proper birth registration process in the country. The aforementioned grants an opportunity to many to exaggerate their daughter's ages to one that serves their purpose of justifying marrying ten year old girls.

The saddest part, yet, is that the women of Nurpur Shahan are not just disempowered but they are also uninformed of their disempowerment. For, only $24.5 \%$ found domestic violence completely unacceptable .

Another critical observation was that most respondents saw their gender at a physical and mental disadvantage to men and hence considered themselves incapable of doing tasks as well as men. This alludes towards the severity with which male superiority is ingrained in these females.

On a more positive end however, even if predominantly for economic betterment, most of the respondents showed an inclination to acquiring education, citing absence of domestic support as their primary hurdle. Many claimed that their parents/husbands were either blatant opponents of female education or merely did not agree with its importance. Financial limitations were spelled out as the second biggest obstacle as most households had an average earning of around PKR 5000-1000.

\section{Conclusion}

As demonstrated by the study, majority of the respondents showed a desire for acquiring education to emancipate themselves economically. This economic liberty for women is the most absent where it is the most needed-the rural localities. For, it is here that women are exploited by men and their deplorable mindsets to the greatest degree .Through proper education, women can reach their full potential and get the ability to stand up for themselves. While many of the holdupsin female education can be solved by government intervention, the one pertaining to lack of support for women literacy cannot asit has to do with the mindset of the people in the society. It is hence not wise to expect the social uplifting of womenwithout first transforming the perceptions held about them and their societal roles.

\section{References}

[1] A.Sathar, Z., \& Raza, B. (1994). Safe motherhood in South Asia:Current status and strategies for change. The Pakistan development review, 1123-1140.

[2] Academy of educational planning and management (2013). Pakistan education statistics report 2012-13.

[3] Ahsan, M. (2003). An analytical review of Pakistan's educational policies and plans. Research papers in education, 259-280.

[4] Ali, S. ( 2006). Why does policy fail? Understanding the problems of policy implementation in Pakistan - a 


\section{International Journal of Science and Research (IJSR) \\ ISSN (Online): 2319-7064}

Index Copernicus Value (2013): 6.14 | Impact Factor (2014): 5.611

neurocognitive perspective. Institute for Educational Development, Karachi.

[5] Alif Ailaan. (2012). 25 million broken promises-The crises of Pakistan's out-of-school children.

[6] Ashraf, E., Afzal, M. Y., \& Shurgeel, H. K. (2012). A review of rural education in Pakistan. Sci.Int.(Lahore), 1013-5316.

[7] Duflo, E. (2012). Women empowerment and economic development. Journal of Economic Literature , 10511079.

[8] Government of Pakistan ministry of finance. (2015). Pakistan economic survey 2014-15. Retrieved from Government of Pakistan ministry of finance: http://www.finance.gov.pk/survey/chapters_15/10_Educ ation.pdf

[9] Junaidi, I. (2014). 50pc of female doctors never work after graduation.

[10] Measure communication. (2000). Retrieved from http://www.prb.org/pdf/IsEducat-Contracept_Eng.pdf

[11] Mirza, H. (2015). Women and education: Yet another divide?

[12] Muhammad, H. (2013). Studying the role of education in eliminating violence against women. Pakistan journal of commerce and social sciences, 405-416.

[13] P.Todaro, M. (2007). Economic development.

[14] Pakistan medical and dental council . (2014).

[15] Parveen, S. (2008). Female education and national development: As viewed by women activists and advocates. 3Bulletin of education and research, 33-41.

[16] Riaz, S., \& Bhatti, M. A. (2010). Problems in the Implementation of National education policies (NEPS) at elementary level. Retrieved from www.aepam.edu.p: http://www.aepam.edu.pk/Files/Publications/NEP.pdf

[17] S.Mustafa. (2014). Learning something from past mistakes. Daily Dawn.

[18] Shaukat, A. (2012). Despite having second worst record for children out of school,UNESCO optmistic.

[19] The Nation. (2012). Literacy level of children in capital slums alarming:The Nation.

[20] The World Bank. (2013).

[21] Trading economics. (2013). Population - female (\% of total) in Pakistan.

[22] UNESCO. (2007). Catalyst for education and gender equality.

[23] UNESCO. (2012). Alarming situation of education in Pakistan.

[24] UNESCO. (2012). Education for all global monitoring report. Retrieved from http://en.unesco.org/gemreport/sites/gemreport/files/EDUCATION_IN_PAKISTAN_A_FACT SHEET.pdf

[25] UNESCO. (2012). Situation analysis of children and women in Pakistan.

[26]UNESCO. (2012). Why Pakistan needs a literacy movement.

[27] UNESCO. (2012). Why Pakistan needs a literacy movement.

[28] UNESCO. (2012). Why Pakistan needs a literacy movement?

[29] UNICEF. (2007). Catalyst for education and gender equality.

[30]Zoë Oxaal, S. B. (1997). Gender and empowerment: Definitions, approaches and implications for policy. 